\title{
Treatment of Postanoxic Intention Myoclonus with Valproic Acid
}

\author{
J. BRUNI, L. J. WILLMORE, B. J. WILDER
}

SUMMARY: Valproic acid in therapeutic doses was used in the treatment of postanoxic intention myoclonus. Disappearance of the myoclonus occurred with marked improvement in the electroencephalogram. No significant side effects were noted. Hepatic function tests were monitored. Determination of valproic acid plasma levels was used to guide therapy. Levels above $55 \mu \mathrm{g}$ were generally requir$e d$. The patient remains free of myoclonus after four and one half months.

RÉSUMÉ: L'acide valproique en doses thérapeutiques a été employé dans le traitement du myoclonus intentionnel post-anoxique. Le myoclonus est disparu cliniquement et il y eut une amélioration importante de l'électroencéphalogramme. Aucun effet secondaire d'importance n'a été observé, même si les fonctions hépatiques étaient suivies constamment. La détermination du taux plasmatique d'acide valproique a servi à guider la thérapie. Il était généralement nécessaire d'obtenir des taux supérieurs à $55 \mu \mathrm{g}$. Le patient est libre de myoclonus après $41 / 2$ mois de traitement.

From the Neurology Service, Veterans Administration Hospital and Department of Neurology, University of Florida College of Medicine, Gainesville, Florida.

Reprint requests to: Dr. L. J. Willmore, Neurology Service (127), Veterans Administration Hospital, Gainesville, Florida 32602, U.S.A.

\section{INTRODUCTION}

Transient myoclonus is not an uncommon occurrence in severe acute anoxic encephalopathy. Multifocal myoclonic jerks may last hours or days and, less often, 2 to 3 weeks. Rarely, the condition continues beyond this period and is accentuated by voluntary movements. When the disorder becomes chronic it is known as postanoxic intention myoclonus or the Lance-Adams syndrome, first described in 1963 (Lance et al., 1963). Since its first description, additional reports have appeared in the literature and its neurochemical basis has created great interest. In the past, moderate improvement has been claimed by mephobarbital (Lance et al., 1963), phenobarbital (Boudin et al., 1963; Lhermitte et al., 1971a), alcohol (Lhermitte et al., 1971a), carbamazepine (Lhermitte et al., 197 la; Hirose et al., 1971), phenacemide (Hirose et al., 1971), chlordiazepoxide (Van Woert et al., 1975), apomorphine (Van Woert et al., 1975), nitrazepam (Muller et al., 1967), diazepam (Lhermitte et al., 1971a; Van Woert et al., 1975; Sherwin et al., 1969), chlorpromazine (Sherwin et al., 1969), iproniazid (Lhermitte et al., 1972), levodopa (Van Woert et al., 1975; Lhermitte et al., 1972; Minoli et al., 1974), clonazepam (Goldberg et al., 1976; Bourdouresques et al., 1971), 5-hydroxytryptophan with or without carbidopa (Lhermitte et al., 1971a; Van Woert et al., 1975; Lhermitte et al., 1972; Guilleminault et al., 1973; Chadwick et al., 1974; DeLean et al., 1976; Van Woert et al., 1977; Growdon et al., (1976), and rarely methysergide (Van Woert et al., 1975; Bedard et al., 1974).

It appears that the benzodiazepines and 5-hydroxytryptophan have been the most promising drugs. Lhermitte et al (1971a) found phenobarbital, carbamazepine, alcohol, diazepam, and 5-hydroxytryptophan (5HTP) to be the most effective drugs in reducing their patient's myoclonus. Chlorpromazine, levomepromazine, dihydroergotamine, haloperidol, methysergide, and methyldopa worsened the myoclonus. They concluded that therapy which increased available serotonin inhibited myoclonic mechanisms, while blocking of serotoninergic and catecholaminergic synapses facilitated it.

A surgical approach to action myoclonus has been attempted by Lhermitte et al (1971b) and Hirose et al (1971). Stereotactic thalamotomy was unsuccessful in both patients.

The most recent pharmacological approach to the treatment of intention myoclonus has been directed to therapy which increases brain serotonin levels. This is based on the suggestion that a deficiency of serotonin may be causally related to post-anoxic intention myoclonus. This theme has been studied in detail by DeLean et al (1976) and again by Van Woert et al (1977).

Valproic acid, a new antiepileptic drug recently licensed in the United States, was given to our patient who developed intention myoclonus as a result of cardiac arrest. The rationale was based on our experience in the use of valproic acid in myoclonic epilepsies with excellent results (Villarreal et al., 1978). It is unlike the more recently reported therapies for the Lance and Adams syndrome, since volproic acid is not known to have any major effect by enhancing serotoninergic mechanisms. 


\section{CASE REPORT}

A 56 year old white male was transferred to the Veterans Administration Hospital May 16, 1978 for further evaluation and treatment of post-anoxic seizures. The patient had a history of hypertension and coronary artery disease. In 1975 he experienced an acute myocardial infarction and in November, 1977 a coronary artery bypass procedure was performed. Past history was negative as was family history. On April 13, 1978 the patient suddenly collapsed and was immediately transferred to the local hospital. The patient was in asystole. However, cardiopulmonary resuscitation restored normal sinus rhythm. The exact duration of anoxia was unknown. The pupils were small and reactive. He remained comatose for four days, then regained consciousness but remained mute. Brief generalized myoclonic jerks were noted within twenty-four hours of the cardiac arrest and these became more prominent during the course of his illness. Respirator assisted ventilation was required for the first few weeks of his hospitalization and the patient developed two episodes of aspiration pneumonia. He was transferred to this hospital for further management of his seizures which had not responded to anticonvulsant therapy (phenytoin and phenobarbital).

Neurological examination on admission revealed an alert but noncommunicative man. He could perform simple commands. Over the next three weeks he gradually became more communicative, but showed some dysarthria and perseveration. Cranial nerve examination was normal except for absent pharyngeal reflexes. Motor system examination revealed frequent sudden, irregular myoclonic jerks involving the facial, trunk, and upper and lower extremity muscles. Proximal muscle groups in the lower extremities were maximally involved and the patient was unable to stand. The myoclonus was accentuated by voluntary movements and could be easily triggered by tactile stimuli. Light and auditory stimuli had no effect. No palatal or diaphragmatic myoclonus was observed. Myoclonus was not observed during sleep. Muscle tone was decreased; there was no focal weakness. Cerebellar function could not be assessed initially because of the frequent myoclonic jerks. After therapy, an action tremor of the upper extremities was present. Sensory examination was normal. Reflex examination revealed marked bilateral snout and grasp reflexes and generalized deep tendon hyporeflexia. Plantar responses were normal.

A computerized tomogram of the brain was normal and an electroencephalogram revealed the occurrence of frequent bisynchronous 70-80 $\mu \mathrm{V}$ spike and polyspike and slow wave discharges localized to the centroparietal regions. The background activity consisted of 7-8 hertz alpha rhythm intermingled with 5 to 7 hertz theta activity (Figure 1). No definite relationship was observed between the myoclonic jerks and the electroencephalographic epileptiform discharges. Hematological investigations, biochemistry, urinalysis, serology, and liver function tests showed no metabolic causes for the myoclonus. Spinal fluid examination showed normal sugar and protein and no cells. An electrocardiogram revealed evidence of previous anterior myocardial infarction and bifascicular block. Phenytoin and phenobarbital administration in therapeutic doses did not ameliorate the myoclonus. He was started on valproic acid $250 \mathrm{mg}$ three times a day and this was gradually increased to $3000 \mathrm{mg} /$ day with disappearance of the myoclonus. Rare low amplitude epileptiform discharges were seen on a repeat electroencephalogram (Figure 2). No clinical side effects except mild initial drowsiness were observed. Valproic acid assay performed as previously reported (Bruni et al., 1978a) revealed a plasma level of $65.1 \mu \mathrm{g} / \mathrm{ml}$. Valproic acid was discontinued on one occasion and subtherapeutic in another and on both occasions myoclonus recurred within 24 to 36 hours and the electroencephalogram showed the recurrence of frequent spike and polyspike and slow wave discharges similar to those observed in the pre-treatment phase (Figure 3).

The patient was maintained on 3000 $\mathrm{mg}$ valproic acid daily with continued control of the myoclonus at four and one half months. Therapeutic plasma valproic acid levels were in the range of 55-65 $\mu \mathrm{g} / \mathrm{ml}$.

\section{SUMMARY}

The term myoclonus is applied to a number of clinically distinct disorders which have in common the occurrence of involuntary, brief muscle jerks which may be symmetrical or asymmetrical, rhythmic or arrhythmic, focal or diffuse. A few isolated myoclonic jerks may be physiological and occur in many healthy people when falling asleep.

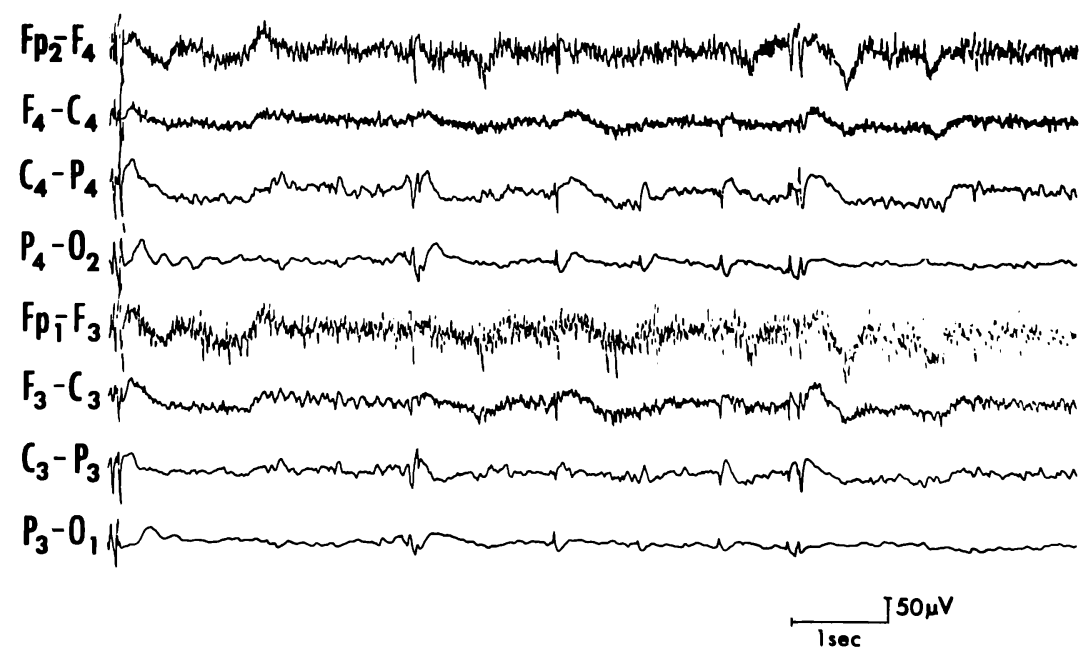

Figure 1-Pretreatment electroencephalogram showing slowing of the background activity and frequent bisynchronous $70-80 \mu \mathrm{V}$ spike and slow wave discharges localized to the centro-parietal regions. 

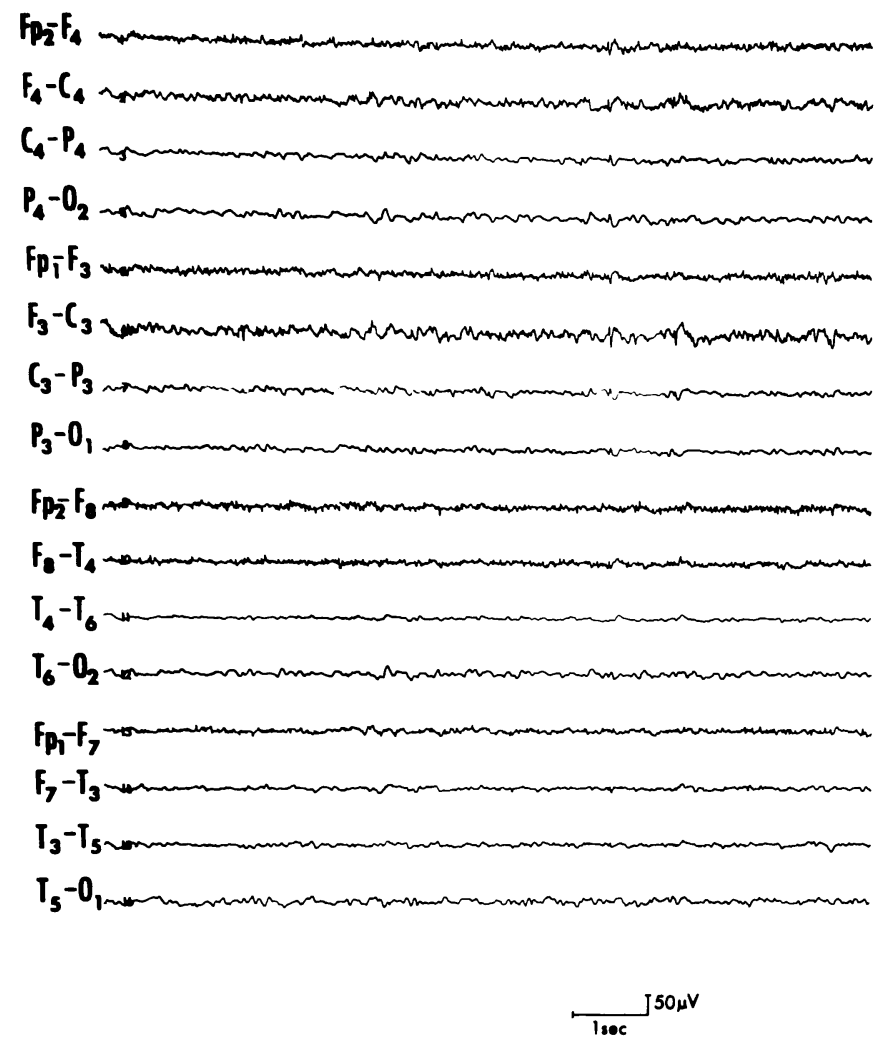

Figure 2-During therapy, the electroencephalogram showed occasional low amplitude $25-50 \mu \mathrm{V}$ spike and slow wave discharges.

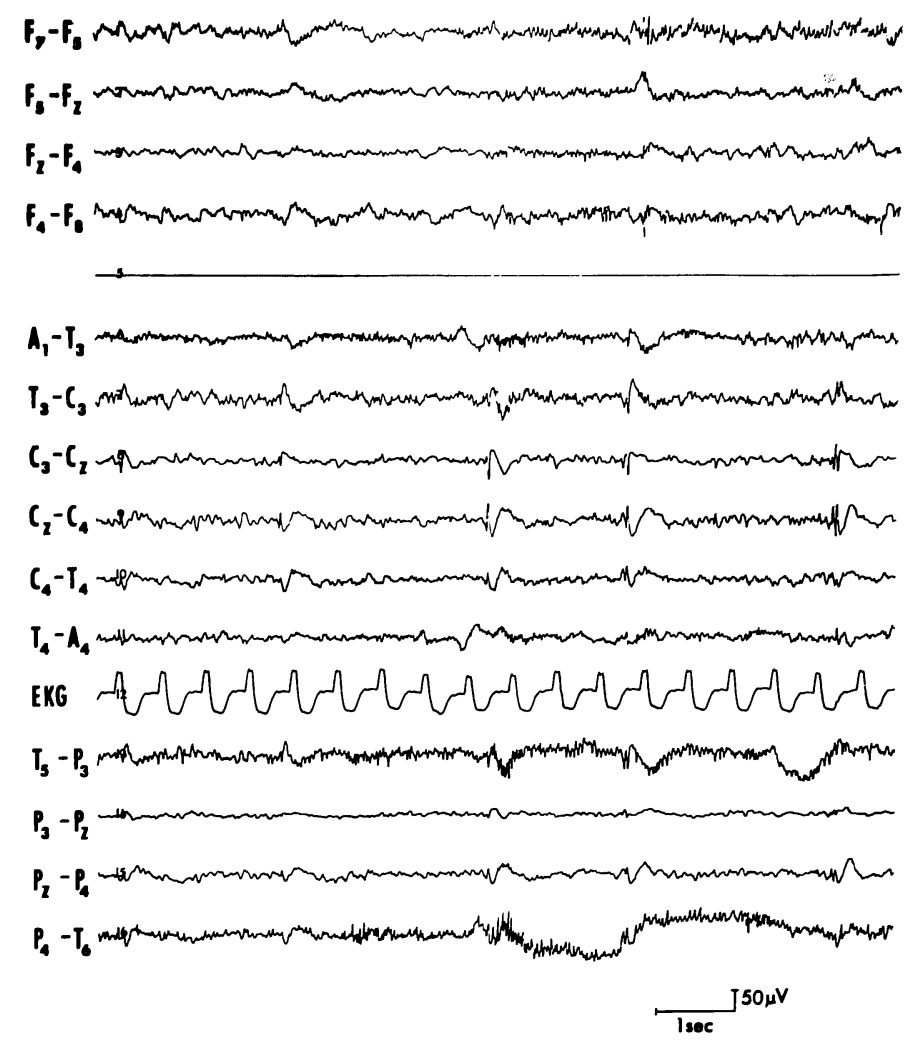

Figure 3-Recurrence of frequent spike and polyspike and slow wave discharges similar to those seen in the pretreatment phase.
The electrophysiologic substrate of myoclonus is varied and Halliday (1975) recognizes three distinct types: extrapyramidal myoclonus, segmental myoclonus, which is rhythmical, invariable, and stimulus-insensitive typical of local lesions of the brainstem or spinal cord, and irregular variable, stimulus-sensitive myoclonus. Intention myoclonus after hypoxic encephalopathy appears to belong to the third category. Lance and Adams (1963) described four patients with this condition. Typically, these patients are in an initial state of coma with or without convulsions. With clearing of the comatose state, dysarthria, mild cerebellar signs, and severe myoclonic jerking of the trunk and extremities accentuated by voluntary movements remain. There is no evidence that the myoclonus resolves spontaneously.

Postmortem pathological studies are wanting. The only reported pathological examination appears in the French literature (Castaigne et al., 1964). Diffuse anoxic changes with gliosis and neuronal loss were found in the striatum, the ventrolateral thalamic nucleus, the subthalamic nucleus, midbrain tegmentum, and the pons. The dentate nuclei were intact and there was only minimal loss of Purkinje cells in the cerebellum. This does not support Lance and Adams' (1963) postulate that the condition results from a lesion of the dentatothalamic pathway, causing dysfacilitation of the ventrolateral thalamic nucleus.

Neurochemical data and therapeutic responses suggest that the neuroanatomic basis for post-anoxic intention myoclonus is a functional and/or structural disturbance of serotoninergic systems. The indoleamine serotonin is a central nervous system transmitter which acts as an inhibitor and depletion may cause a seizure discharge. However, treatment of seizure disorders with serotonin has had limited success. The more recent pharmacological studies on intention myoclonus have provided indirect proof that serotonin is deficient in myoclonic seizures (Van Woert et al., 1975; Chadwick et al., 1974; De Lean et al., 1976; Van Woert et al., 1977; Growdon et al., 1976). Direct proof is lacking. The beneficial effects of serotonin precursors and low CSF 5hydroxyindoleacetic acid (metabolic product of serotonin metabolism) levels which improve with therapy have led these workers to believe that post-anoxic intention myoclonus is a serotonin deficiency disease. The approach to its treatment is similar to the pharmacological approach to the treatment of Parkinson's disease. Five-hydroxytryptophan crosses the blood brain barrier and in experimental animals causes an increase in brain serotonin and 5-hydroxyindoleacetic acid concentrations (Guilleminault et al., 1973).

Some observations suggest that there also may be a dopamine deficiency in post-anoxic intention myoclonus (Van Woert et al., 1975; Lhermitte et al., 1972). Apomorphine 
and small doses of levodopa caused mild improvement of some patients who had low CSF homovanillie acid levels.

Valproic acid therapy for postanoxic intention myoclonus has not been previously reported, although it has been found to be extremely useful for myoclonic seizure states. This broad spectrum antiepileptic drug is also useful in other seizure disorders. It has not been found useful in idiopathic segmental myoclonus (Unpublished data Bruni, Willmore, Wilder). Its pharmacological mechanism of action is uncertain but it may be through an elevation of brain gamma aminobutyric acid (GABA) in synaptic regions. Elevations in total brain GABA levels have been reported (Godin et al., 1969; Harvey et al., 1975). However, it appears that this may occur only with doses well above those used in clinical situations. There is sufficient evidence to suggest a role for GABA as an inhibitory neurotransmitter. The vertebrate neurones most clearly identified by chemical, physiological, and immunochemical criteria as GABAergic are the cerebellar Purkinje cells. High concentrations of GABA in human brains are found in the substantia nigra, globus pallidus, hypothalamus, and caudate nucleus (Perry et al., 1971).

GABA deficiency has been implicated in pyridoxine deficiency seizures although pyridoxine is involved in other metabolic pathways. Thus, the relationship between changes in GABA and seizures is uncertain. The action of valproic acid has yet to be identified. It is interesting to note that it is most useful in seizure disorders (petit mal and myoclonic epilepsies) in which no disturbance of GABA metabolism is generally implicated. Plasma levels required are within the therapeutic range for the treatment of other seizure disorders $(50-100 \mu \mathrm{g} / \mathrm{ml})$ (Bruni et al., 1978b). The drug generally has low toxicity, however because of occasional hepatotoxicity, liver function should be monitored (Willmore et al., 1978).

Valproic acid can cause some elevation of the cerebral concentration of serotonin, although this effect is not related to its anticonvulsant activity
(Horton et al., 1977). The excellent response to our patient to this antiepileptic drug leads us to conclude that further trials of valproic acid in cases of intention myoclonus are indicated.

\section{ACKNOWLEDGEMENTS}

Dr. Bruni is sponsored by the Ontario Ministry of Health. Appreciation is extended to Lisa Benedict for her secretarial assistance, and to David Gratz for assistance in preparation of illustrations.

\section{REFERENCES}

BEDARD, R. and BOUCHARD, R. (1974). Dramatic effect of methysergide on myoclonus. Lancet 1:738.

BOUDIN, G., PEPIN, B., LAURAS, A., et al. (1963). Myoclonies intentionelles persistances apres reanimation cardiaque. Rev. Neurol. (Paris) 109:468-472.

BOURDOURESQUES, J., ROGER, J., KHALIL, R., et al. (1971). A propos de 2 observations de syndrome de Lance et Adams. Effect therapeutique de RO-054023. Rev. Neurol. (Paris) 125:306-309.

BRUNI, J., WILDER, B. J., WILLMORE, L. J., et al. (1978) Steady-state Kinetics of Valproic Acid in Epileptic Patients. Clin. Pharmacol. Ther. 24:324-332.

BRUNI, J., WILDER, B. J., WILLMORE, L. J., et al. (in press). Pharmacokinetics of steady state valproic acid in epileptic patients. J. Clin. Pharmacol. Ther.

CASTAIGNE, P., CAMBIER, J., ESCOUROLLE, R., et al. (1964). Observation anatomoclinique d'un syndrome myoclonique post-anoxique. Rev. Neurol. (Paris) 111:60-73.

CHADWICK, D., REYNOLDS, E. H. and MARSDEN, C. D. (1974). Relief of action myoclonus by 5-hydroxytryptophan. Lancet 2:111-112.

DELEAN, J., RICHARDSON, J. C. and HORNYKIEWICZ, O. (1976). Beneficial effects of serotonin precursors in postanoxic action myoclonus. Neurology 26:863-868.

GODIN, Y., HEINER, L., MARK, J., et al. (1969). Effects of di-n-propylacetate, an anticonvulsant compound, on GABA metabolism. J. Neurochem. 16:869-873.

GOLDBERG, M. A. and DORMAN, J. D. (1976). Intention myoclonus: Successful treatment with clonazepam. Neurology 26:24-26, 1976

GROWDON, J. H., YOUNG, R. R. and SHAHANI, B. T. (1976). L-5-hydroxytryptophan in the treatment of several different syndromes in which myoclonus is prominent. Neurology 26:1135-1140.

GUILLEMINAULT C., THARP, B.R. and COUSIN, D. (1973). HVA and 5HIAA CSF measurements of 5HTP trials in some patients with involuntary movements. J. Neurol. Sci. 18:435-441.

HALLIDAY, A. M. (1975). The neurophysiology of myoclonic jerking -- a reappraisal. In "Myoclonic Seizures". Excerpta Medica Princeton, Ed. Charlton, M. H. pp. 1-29.
HARVEY, P. K. P., BRADFORD, H. F. and DAVISON, A. N. (1975). The inhibitory effect of sodium n-dipropylacetate on the degradative enzymes of the GABA shunt. FEBS Lett. 52:251-254.

HIROSE, G., SINGER, P. and BASS, N. H (1971). Successful treatment of posthypoxic action myoclonus with carbamazepine. J.A.M.A. 218:1432-1433.

HORTON, R. W., ANLEZARK, G. M., SAWA, McB., et al. (1977). Monoamine and GABA metabolism and the anticonvulsant action of di-n-propylacetate and ethanolamine-O-sulphate. Eur. J. Pharmacol. 41:387-397.

LANCE, J. W. and ADAMS, R. D. (1963). The syndrome of intention or action myoclonus as a sequel to hypoxic encephalopathy. Brain 86:111-136.

LHERMITTE, F., MARTEAU, R. and DEGOS, C. F. (1972). Analyse pharmacologique d'un nouveau cas de myoclonies d'intention et d'action post-anoxiques. Rev. Neurol. (Paris) 126:107-114.

LHERMITTE, F., PETERFALVI, M., MARTEAU, R., et al. (1971a). Analyse pharmacologique d'un cas de myoclonies d'intention et d'action post-anoxiques. Rev. Neurol. (Paris) 124:21-31.

LHERMITTE, F., TALAIRACH, J., BUSER, P., et al. (197/b). Myoclonies d'intention et d'action post-anoxiques. Etude stereotaxique et destruction du noyau ventral lateral du thalamus. Rev. Neurol. (Paris) 124:5-20.

MINOLI, G. and TREDECI, G. (1974). Levodopa in treatment of myoclonus. Lancet 2:472.

MULLER, H. R., KAESER, H. E. and DUNANT, J. H. (1967). Aspects cliniques et electrophysiologiques des myoclonies postanoxiques, specialment du myoclonus d'action. Rev. Neurol. (Paris) 117:105-110.

PERRY, T. L., BERRY, K. HANSEN, S., et al. (1971). Regional distribution of amino acids in human brain obtained at autopsy. J. Neurochem. 18:513-519.

SHERWIN, I. and REDMON, W. (1969). Successful treatment in action myoclonus. Neurology 19:846-850.

VAN WOERT, M. H. and SETHY, V. H. (1975). Therapy of intention myoclonus with L-5-hydroxytryptophan and a peripheral decarboxylase inhibitor, MK486. Neurology 25:135-140.

VAN WOERT, M. H., ROSENBAUM, D., HOWIESON, J., et al. (1977). Long-term therapy of myoclonus and other neurologic disorders with L-5-hydroxytryptophan and carbidopa. N. Engl. J. Med. 296:70-75.

VILLARREAL, H. J., WILDER, B. J., WILLMORE, L.J., et al. (1978). Effect of valproic acid on spike and wave discharges in patients with absence seizures. Neurology. 28:886-891.

WILI.MORE, L. J., WILDER, B. J., BRUNI, J., et al. (1978). Effect of valproic acid on hepatic function. Neurology. 28:961-964. 